Administrative Issues Journal: Connecting Education, Practice, and Research, Winter 2020, Vol. 10, No. 2: 1- 17. DOI: 10.5929/2020.10.2.1

\title{
The Unpaid Internship: Benefits, Drawbacks, and Legal Issues
}

\author{
Philip C. Rothschild, Ph.D. \\ Missouri State University \\ Connor L. Rothschild \\ Rice University
}

\begin{abstract}
This article hopes to clear up some of the confusion surrounding unpaid internships by discussing who participates in such internships, the merits and drawbacks relative to paid internships, and the relevant legal issues. This summary of existing research provides several key insights, which are of interest to potential interns as well as educators. For students, the literature suggests that unpaid internships are different from their paid counterparts in a variety of ways and pose certain risks that paid internships do not. On an institutional level, this paper documents the unique legal environment surrounding the unpaid internship and notes the unique liabilities program administrators may face if they fail to act with caution.
\end{abstract}

Keywords: unpaid internships, experiential learning, educators, career outcomes, legal issues

Categories: practice, literature review, business education

\section{Introduction}

Inpaid internships have long been a subject of intense scrutiny among universities, employers, and politicians. Many questions have been posed regarding unpaid internships, and some remain unanswered. The authors set out to discover what the literature says about unpaid internships compared to paid internships across all disciplines. The hope is that educators can then better evaluate their academic programs and discern what they can do to take advantage of the benefits, avoid the drawbacks, and stay alert to the politics of unpaid internships.

First, we examine who currently participates in internships. Next, we look at what the research reveals about the benefits and drawbacks of unpaid internships as compared to paid internships. We then review the current political and legal issues surrounding unpaid internships.

\section{Who Participates in Unpaid Internships}

Although there is no official record of the number of internships in the United States (Bacon, 2011), estimates put the number somewhere around 1.5 million in any given year, with half of them unpaid (Reid, 2015). Thirty-eight percent of these unpaid internships occur at for-profit companies (Pasternack, 2015). Participating in an internship seems to be of escalating importance to current students, with $84 \%$ of college students reporting an intention to intern before graduation (Reid, 2015). 
The number of unpaid internships may fluctuate given the United States' economic performance in a given year. In the wake of the 2008 Great Recession, the scarcity of jobs led an increasing number of recent graduates to unpaid internships in the hopes of developing a connection with a potential employer (Greenhouse, 2012). Following modest growth in the first half of 2013, the International Labour Organization ("Recent US Labor Market Data," 2013) concluded that the "number of new jobs created remains insufficient to redeem the jobs lost during the recession and additional jobs needed to keep up with growth in the labor force" (para. 5). This, compounded with the especially high unemployment rate of recent graduates, led some to argue that unpaid internships were necessary to get an advantage in the highly competitive job market (Pasternack, 2015; Burke \& Carton, 2013).

The demographic profile of those who participate in internships varies if the intern is provided compensation for their work. Previous studies have shown that women are significantly more likely than men to engage in unpaid internships (Gardner, 2010). Students pursuing degrees in the humanities and social sciences are more likely to participate in unpaid internships than their STEM counterparts, possibly due to the nature of their internship provider's workplace (Crain, 2016; Gardner, 2010). Extending past the university environment, these differences in demographics among paid and unpaid interns "interacts with gender and field of academic major to produce inequality in postgraduate outcomes by field of study" (Townsley et al., 2017, p. 8).

\section{The Benefits of the Unpaid Internship}

The pedagogical foundation supporting unpaid internships relies upon Kolb's (1984) experiential learning theory, which posits that experiences are crucial to one's learning process. More specifically, experiential learning can be described as "a holistic integrative perspective on learning that combines experience, perception, cognition, and behavior" (Kolb, 1984, p. 21). It unfolds in a four-step process: concrete experience, reflective observation, abstract conceptualization, and active experimentation (Kolb, 1984, p. 30). Substantiating Kolb's findings, Cantor (1997) argued that experiential learning is a "necessary component of formal instruction in colleges and universities" because 1) university faculty want their students to be more competitive in a tight job market, 2) college students desire a wider variety of modes of learning, and 3) many important metrics of a college's success (retention, graduation, and recruitment rates) are affected by the presence of experiential learning (Cantor, 1997, p. 5-6). More recently, Haque (2017) detailed the importance of experiential learning for students, university faculty, and those in industry.

Important to this review is the application of experiential learning to the internship experience. Simons et al. (2012) have shown that experiential learning improves a student's "personal, civic, and professional development," and that, as a corollary, internship programs are "beneficial for all involved" (p. 325). Students participating in internship programs that foster experiential learning reported higher levels of cultural competency, a greater understanding of their field, and increased confidence in their preparedness for entering the workforce or pursue higher education. Moran's (2013) study of students participating in internship programs found that interns appreciate the tenets of experiential learning that are present in their experience while also seeing the internship as an important stepping stone in their career path.

Stack and Fede (2017) have explored the internship's impact on soft skill development, an increasingly important trait in today's globalized and competitive workforce (Andrews \& Higson, 2008; Pellegrino \& Hilton, 2012). Employers today place more importance on soft skills than any other type of skill (Finch et al., 2013). Thus, fostering a heightened development of soft skills is of much pedagogical importance. When surveying both internship supervisors and the interns themselves, Stack and Fede 
found significant increases in the four domains tested (communication, initiative, teamwork, analytical skills) as well as significant increases in every related subcategory.

Although much literature has postulated that internships are a good tool by which to teach the lessons of experiential learning, there is scant research on the experiential value of unpaid internships, specifically, and little analysis of the connection between financial compensation and experiential learning. Generally speaking, research has documented that unpaid interns may report lower levels of satisfaction with their internship experience, perhaps indicating they may feel they learned less than their paid counterparts (Crain, 2016). This could partially be explained by the fact that unpaid interns may spend a greater proportion of their time doing clerical work and less time on professional duties than paid interns (Farthing-Nichol, 2014). If it is true that unpaid interns carry out more menial tasks than paid interns, then they are not receiving the same benefits of experiential learning as those receiving compensation, an area of potential criticism for unpaid internships. Further research should explore the presence of experiential learning in unpaid internships.

Some defend unpaid internships by arguing that their value is inherently rooted in the development of certain skills. Employers may justify a lack of financial compensation by arguing the student's development is valuable enough to warrant the absence of pay (Pasternack, 2015). This, however, is once again refuted by the propensity toward routine, menial tasks among unpaid interns. Because unpaid interns spend less time developing professional skills through meaningful work and report lower levels of satisfaction than their paid counterparts, it should be difficult for internship providers to argue their employment opportunity supplants the need for payment.

Despite the lack of specific research on the pedagogical value of unpaid internships, internships are still generally considered to be a great avenue to experiential learning. One important question moving forward is whether interns' career outcomes are as good as pedagogy suggests they will be.

\section{The Employer's Perspective on Unpaid Internships}

According to employers, internships remain one of the best options for college students. A 2012 survey of employers found that internships were the most important factor an employer considered when making their decision to hire a recent college graduate, concluding that having an internship "is the single most important credential for recent college graduates to have on their resume in their job search among all industry segments" ("The role of higher education," 2012, p. 11).

Employers claim that participation in an unpaid internship specifically is one of the most important factors they consider in their hiring process. According to $79 \%$ of respondents in the aforementioned survey, completing an unpaid internship has a positive impact on a prospective employee's chances of being hired, beating out volunteer work, employment in an unrelated field, and enrollment in a graduate or certification program ("The role of higher education," 2012, p. 84).

Given this, an important research question is whether employers detect a difference in quality of work done by paid and unpaid interns. In one study of internship participants at Endicott College, the majority of employers reported seeing no discernible difference in job performance between those who received compensation for their work and those who did not (Saltikoff et al., 2018).

In fact, many employers report that interns receiving academic credit for their work are "more accountable" and "seem to care more about their level of performance and the future impact it could have on their GPA for grad school or future internships" (Saltikoff et al., 2018, p. 11). This substantiates the theory that unpaid internships are most beneficial for all parties involved if the intern at least receives academic credit for their work.

One focus group of intern supervisors revealed the sentiment that those interning without compensation may perform better than paid counterparts because it would signal to the employer "that 
the candidate has gone above and beyond." In the employers' view, an unpaid internship "shows passion" (Saltikoff et al., 2018, p. 11).

These findings show that employers, at least nominally, do not have a strict preference between students who participated in paid and unpaid internships - and sometimes say they prefer unpaid interns. More important to a student's decision to participate in an internship program, however, may be an internship's effect on the student's career outcomes.

\section{The Short-Term Career Success of Unpaid Internships}

In the short term, the literature suggests participation in unpaid internships makes students worse off. One important dichotomy to be made, as per usual when considering the effectiveness of internships, is between paid and unpaid internships. Evaluating the effectiveness of compensation on an intern's work ethic and career prospects has long been a popular topic of literature.

Paid interns have an advantage when it comes to assuming employment directly after graduation, as paid internships are positively correlated with being given a job offer prior to graduation. Unpaid interns, however, report no such immediate benefit (Crain, 2016). Surprisingly, researchers often link unpaid internship participation to a decline in this objective measure of short-term career success. In fact, unpaid internships have been recorded as having a "strong negative influence" on the temporal dynamic of students' job search process (Crain, 2016, p. 7). In other words, students who participate in unpaid internships take longer to find their first job following graduation than even those who do not participate in internships at all. This could, in part, be explained by the findings of Guarise and Kostenblatt (2018), who note that individuals who participate in unpaid internships are more likely to pursue post-graduate degrees than their counterparts receiving compensation. The time gap in job acceptance among unpaid interns could also substantiate the pedagogical conception of unpaid internships as a stepping stone to additional career options-not an opportunity to directly connect with employers in industry, as is often the case with paid internships (Crain, 2016).

Also concerning is the fact that unpaid interns earn, on average, over $\$ 16,000$ less in their first year working than paid interns, and, shockingly, over $\$ 1,300$ less than those who never participated in an internship (Pisko, 2015, p. 629). This could be explained by demographics; Crain (2016) has noted that women and students majoring in the arts and humanities are among those most likely to engage in unpaid internships. These groups may also be subject to lower pay. Reid (2015) attributes the lower starting salaries of former unpaid interns to "the tendency of unpaid internships to depress interns' expectations and to create overidentification with employers" (p. 1378).

In the short term, unpaid internships are typically depicted by researchers as a worse option than paid internships, and sometimes even worse than no internship at all. As counterintuitive as it may sound, surveys of prior interns show their first job following graduation is both delayed temporarily and subject to lower payment than those who receive compensation for their internship. The mismatch in short-term career success between paid and unpaid interns could be the result of myriad factors, ranging from the demographic profiles of interns, to their majors, to attitudinal shifts the intern underwent during their internship experience, to the discrepancies in the interns' pursuits of higher education.

\section{The Long-Term Career Success of Unpaid Internships}

The long-term career prospects for students who engage in unpaid internships are more promising. One 2018 study revealed no significant difference in salaries between those who participated in paid and unpaid internships in college (Saltikoff et al., 2018). 
Generally speaking, internships are considered a great path to better career success. A range of empirical literature has long demonstrated that undergraduates with internship experience record better career success by almost every metric. Sanahuja and Ribes' (2015) systematic review of the literature on business internships' effectiveness concluded that internships improve a student's prospects in a career-oriented job post-graduation, improve their social skills, and help narrow their career path. Guarise and Kostenblatt's (2018) recent study of graduates showed no difference in longterm career success between former paid and unpaid interns, but did reveal that graduates with any type of internship had annual salaries on average $\$ 2,082$ higher than those with no internship experience.

Although the short-term career success of unpaid interns may be lacking in comparison to paid interns, this should not be a reason to avoid unpaid internships. There are likely numerous factors at play that account for such a discrepancy. More importantly, the long-term career success of interns is well-documented in literature and indicates that internships of all stripes are a path to better career outcomes.

\section{The Drawbacks of the Unpaid Internship}

Despite the benefits of unpaid internships in the long term, there are a few drawbacks of the unpaid internship that all potential interns (and internship providers) should understand.

\section{Social Mobility/Low Income Accessibility}

One common criticism levelled against unpaid internship programs is that they effectively disbar and exclude low income individuals from participating and receiving the same opportunities as their wealthy counterparts. While wealthy students have the resources and capital to take up work without compensation, unpaid interns often may not have the means to provide for themselves while working for free. As a result, the critical narrative argues unpaid internships expand the ever-widening gap between wealthy and worse-off individuals in America (Eisenbrey, 2012).

This narrative seems convincing. However, evidence may disprove the hypothesis that unpaid internships exclude poor students. Gardner's (2010) study revealed that the relationship between family income and participation in unpaid internship is the opposite of what would be expected: among students with family income below $\$ 80,000,46 \%$ engaged in an unpaid internship, $6 \%$ higher than the participation rate of $40 \%$ for students with family income above $\$ 80,000$.

There is still a possibility that unpaid internships disadvantage poorer students by providing paid interns with more professional skills than their unpaid counterparts. Farthing-Nichol (2014) has noted that paid interns at for-profit companies spend $44 \%$ of their time on professional, skill-building duties and $24 \%$ on clerical duties, while unpaid interns spend $33 \%$ of their time on professional duties and $31 \%$ on clerical duties. Among unpaid interns, wealthier students are more likely to intern at larger, for-profit companies - receiving greater access to "resume building internships" - and poorer students are more likely to intern at small non-profits doing menial, clerical tasks (Fink 2013).

This discrepancy is also important given the fact that, as one study suggests, for-profit companies (where wealthier students intern) extend full-time employment offers to $55 \%$ of interns, while non-profits (where poorer students intern) only offer full-time employment to $5 \%$ of their interns (Brooks \& Greene, 1998). This may also in part explain the aforementioned literature regarding the lower incomes of former unpaid interns in the short term following graduation (Pisko, 2015). When debating the legitimacy of the claim that unpaid internships harm social mobility, however, long-term 
career success should be the preferred metric because moving up the socioeconomic ladder is not necessarily supposed to be a quick process and may instead take years or decades in the workplace.

\section{Lack of Legal Protections}

One seldom-discussed implication of participating in an unpaid internship is the lack of legal protections afforded to those who don't receive compensation for their work. Federal employment law prevents discrimination through three main statutes: Title VII of the Civil Rights Act of 1964 (42 U.S.C. $\S$ 2000e-2), the Age Discrimination in Employment Act (29 U.S.C. §§ 621-634), and the Americans with Disabilities Act (42 U.S.C. §§ 12101-12214).

The decisions of two key court cases, O'Connor v. Davis and Smith v. Berks Community Television, suggest many of these protections do not extend to unpaid interns because they do not receive compensation and, thus, are not employees (Svacina, 2012). More recently, in 2013, a federal district court ruled in Wang v. Phoenix Satellite Television US, Inc. against an unpaid intern who put forth claims of repeated sexual harassment by her bureau chief. Citing the decision of $O^{\prime}$ Connor, the court ruled that the intern was not an employee who would normally be protected by New York state employment law (Wang v. Phoenix Satellite Television US, Inc., 2013).

Yamada (2016), who has documented that this case, among others, suggests that the court's ruling fits the trend of interns not receiving protection from harassment because they fail to meet the statutory definition of "employee." When investigative journalists at ProPublica asked U.S. Equal Employment Opportunity Commission spokesman Joseph Olivares about intern protections, he replied, "At least with respect to the federal law that we enforce, an unpaid intern would not be legally protected by our laws prohibiting sexual harassment" (Hickman \& Thompson, 2013, para. 5).

Given the language of modern antidiscrimination statutes, it is likely this problem would extend beyond just sexual harassment: Svacina (2012) has concluded that it is similarly likely that unpaid interns "would not be protected from age or disability discrimination while in the workplace" because the interns are not considered "employees" (p. 82).

The presence of harassment and discrimination against unpaid interns should be of special interest to universities who encourage their students to participate in internships. While an intern's employer may not be held responsible for claims of discrimination or harassment, the student's university may instead be held liable. In Gross v. Family Services Agency and Nova Southeastern University, a student intern sued her university for negligence when she was assaulted in a parking lot of her place of work, which the university knew had a history of assault incidences (Gross v. Family Services Agency and Nova Southeastern University, 1998). The court sided with the student intern. This case may suggest that universities can be held responsible for the harms brought to their student if they are aware of the risk to which they are subjecting the student. Consequently, scholars suggest universities should be proactive in protecting students from potentially dangerous situations, taking steps such as monitoring the intern's experience and ending partnerships with potentially dangerous or disreputable organizations (Svacina, 2012).

The Federal Intern Protection Act of 2017 was one of the first serious federal efforts to prohibit workplace discrimination against unpaid interns (Federal Intern Protection Act of 2017). Unfortunately, the bill has not been touched since it was passed to the Senate in May of 2017; however, we can hope that it signals progress moving forward.

Despite inaction on the federal level, a few states have led the way in passing legislation that prevents interns from discrimination. Connecticut, Oregon, New York, Maryland, and Illinois have all passed legislation that protects interns from sexual harassment, discrimination, or both (Lachman, 2015). 
Notwithstanding the presence of a few state-level efforts to mitigate harassment and discrimination against interns who do not qualify as employees, federal law still fails to protect unpaid interns. Important to intern program coordinators is the fact that the university that sends the intern to their place of employment may be held liable if the student is harmed. Although it may not be the primary consideration of potential interns nor the academics debating the ethics of unpaid internships, the lack of defense against workplace harassment is a drawback of unpaid internships that should not be ignored.

\section{The Legal Issues of the Unpaid Internship}

Aside from the apparent benefits and drawbacks of unpaid internships, many authors have studied the complex legal implications of such internships. Most begin their historical analyses of the unpaid internship with a look at the Fair Labor Standards Act (FLSA), a far-reaching response to the Great Depression passed by President Franklin D. Roosevelt in 1938. Durrant (2013) has noted that the FLSA contains important provisions which define terms such as employee and set the minimum wageespecially relevant when considering one's conception of the internship. Under the FLSA, unpaid internships would likely be considered categorically illegal because the Act defined an employee as "any individual employed by an employer" and also declared that employees must be paid at least the minimum wage for the first 40 hours of a workweek and at least one and one-half times the minimum wage for all hours subsequently (Fair Labor Standards Act of 1938).

Nine years later, in Walling v. Portland Terminal Co., the Supreme Court gave renewed attention to the legality of unpaid internships. In Walling, the Court decided that railroad trainees-individuals training for employment yet not being financially compensated-were not considered employees because they derived no "immediate advantage" from their work (Walling v. Portland Terminal Co., 1947). The Court's decision in Walling was of the utmost importance, described by Reid (2015) as "the seminal unpaid-worker case" (p. 1380). The decision effectively redefined the term employee as once provided by the FLSA, separating traditional employees defined as "any individual employed by an employer" from trainees who worked not for financial compensation but instead for their own benefit. This established what is now referred to as the "trainee exception" to the FLSA's definition of an employee (Budd, 2015, p. 463).

More than six decades later, the Wage and Hour Division of the Department of Labor (DOL) codified the trainee exception into law with Fact Sheet \#71 (Appendix A). Fact Sheet \#71 was issued in 2010 and provided a six-prong test (based on the criteria outlined in Walling) used to determine if an intern should be considered an employee and, thus, be financially compensated for their work (Svacina, 2012). If an internship failed to meet the criteria within the Fact Sheet, an intern would be considered an employee (and be subject to compensation) rather than a trainee (U.S. Department of Labor Wage and Hour Division [DOL], 2010). One important detail regarding Fact Sheet \#71's six-prong test is that it is conjunctive, meaning all six criteria must be met in order for an individual to be considered a trainee. Also relevant is that the criteria provided by Fact Sheet \#71 only apply to for-profit organizations, excluding government or non-profit organizations (Bacon, 2011).

Fact Sheet \#71 was a sort of warning signal given to for-profit firms by the Obama administration. Bacon (2011) remarked that it sent "a clear message to for-profit firms that the current administration is likely to increase its enforcement of the rules" (p. 68). This could not perhaps be made clearer than with the words of the former director of the Department of Labor's Wage and Hour Division, Nancy J. Leppink, who said at the time: "If you're a for-profit employer or you want to pursue an internship with a for-profit employer, there aren't going to be many circumstances where you can 
have an internship and not be paid and still be in compliance with the law" (Greenhouse, 2010, para. 5). The years that followed proved that the Department of Labor's warning should have been taken seriously.

In 2013, the six-prong test was put to test in Glatt v. Fox Searchlight Pictures Inc. when three interns at Fox Searchlight Pictures (Fox) sued their employer for violating minimum wage laws by not paying them. Using the six-prong test, a Federal District Court judge in Manhattan decided that the interns qualified as "employees" and were deserving of compensation (Sterbenz, 2013). Following the decision, one attorney, who focuses on employment law, wrote that the decision was "a complete game changer," positing that unpaid internships would "go away fairly quickly" as a result (Mihelich, 2013, para. 7). Indeed, employers quickly started modifying their internship programs (Greenhouse, 2013). Many lawsuits were filed against employers after the six-part test was created and the Fox Searchlight decision was announced, leading to settlements which could in some instances cost employers hundreds of thousands of dollars (Easterly, 2018). The Fox Searchlight decision, in one news article, was described as "the court ruling that could end unpaid internships for good" (Weissman, 2013).

It seems that unpaid internships, however edifying to the student, were impossible to legally justify given the framework of Fact Sheet \#71. The legal requirements contained within Fact Sheet \#71 were incredibly difficult to satisfy-especially considering their conjunctive nature. Compliance with Fact Sheet \#71 has been described by legal experts as "difficult" (Budd, 2015, p. 469) and "nearly impossible" (Curiale, 2010, p. 1531). Reid (2015) noted that the requirements were so strict that almost every unpaid academic internship fails to satisfy the Fact Sheet's test. Reid (2015) construed the strict legal interpretation of Fact Sheet \#71 as reason for concern, as it had the potential to force employers to "extinguish" unpaid internships-as was seen following the Fox Searchlight decision-despite the opportunities' potential to edify the student (p. 1386).

It was against this new backdrop that some academics started the call to eliminate the requirement for the internship in their own departments and universities. Following the creation of the six-prong test, Schoepfer and Dodds (2010) called for the elimination of the internship requirement that is often present in the field of sport management. They argued the internship was made obsolete and counterproductive both because of legal debacles and the fact that experiential learning can be actualized in other circumstances and through other opportunities.

The legal landscape surrounding unpaid internships, however, again changed in 2015 when the U.S. 2nd Circuit Court of Appeals in New York vacated the prior Glatt v. Fox Searchlight Pictures, Inc. decision. Circuit Court Judge John Walker strayed away from the Fact Sheet's six-prong test in his determination of whether the three Fox interns should be considered employees, claiming the test was "too rigid" to be applied (Miller, 2016, para. 10), echoing the sentiments of many legal experts (Reid, 2015; Curiale, 2010; Budd, 2015). Rather, the court applied a new test that questioned whether the company that hired the intern or the individual at hand was the "primary beneficiary" of the work relationship. In other words, the court ruled that the interns at Fox would be considered employees only if it could be proven that Fox gained more from their internship than the interns did. This decision stood directly in opposition to the efforts of President Obama's DOL to regulate and prevent unpaid internships. Indeed, Johnson (2016) wrote that for-profit corporations were "celebrating" the court's holding in Fox Searchlight (p. 1128).

The final and most recent change to the legality of the unpaid internship occurred in January 2018, when President Trump's Labor Department codified the primary beneficiary test into law with an update to Fact Sheet \#71 (Appendix B). More specifically, the DOL rescinded the six-prong test and introduced a seven-factor test, which is used to determine the primary beneficiary in a working relationship. Importantly, the seven-factor test is not conjunctive, but instead each factor is meant to be 
weighed independently. If a court decides that, in totality, the primary beneficiary of a working relationship is the intern-as determined by the seven factors in the new fact sheet-the intern can be employed without compensation (U.S. Department of Labor Wage and Hour Division [DOL], 2018). Similar to the decision in Fox Searchlight, the new rules set forth by the Trump administration's DOL were praised by for-profit corporations hoping to hire unpaid interns. As one attorney who works closely with employment law put it, the "standard that the department is setting forth is easier for companies to satisfy in terms of internships qualifying as unpaid" (Greenfield, 2018, para. 4). Another group of employment law specialists wrote that the DOL is "moving aggressively to clarify that most internships can be unpaid" ("New DOL Rule," 2018).

Following the Walling decision, the issue of the legality of unpaid internships had remained a relatively untouched issue for half a century. It wasn't until the last decade that the discussion has been reinvigorated, with two presidents taking two radically different approaches to the issue. During the Obama presidency, many employers started paying their interns or ceased offering internships entirely. Under President Trump, the legal landscape seems less labyrinthine than it once did. Employers, within reason, should feel freer to hire interns without compensation, as long as they are mindful that their interns are the primary beneficiary of the working relationship.

\section{Conclusion}

It's clear the debate surrounding the benefits and drawbacks of paid and unpaid internships will be ongoing. There seems to be significant agreement, however, that internships, generally speaking, are viewed as positive for both students and employers. It also seems evident the political landscape will influence the legal status of unpaid interns and whether or not for-profit employers will offer unpaid internships in the future. Nevertheless, there are some important takeaways for educators.

The findings highlighted in this review of the literature (summarized in Appendix $\mathrm{C}$ ) move us closer to acquiring objective data to support our "hunches" about the value of paid and unpaid internships. This review outlines the mostly positive benefits of internships for both the students and the employers. Also highlighted are some of the drawbacks and legal issues surrounding internships. Educators can now use the benefits to gain the support of colleagues and administrators hesitant to require internships and to inspire students to complete internships. Additionally, the drawbacks and legal issues identified in this paper can be used to improve the quality of internships offered and perhaps influence the types of internships educators encourage. 


\section{Appendix A}

Fact Sheet \#71: Internship Programs Under The Fair Labor Standards Act (April 2010)

\section{U.S. Department of Labor Wage and Hour Division}

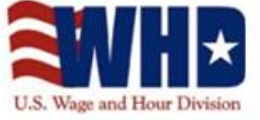

(April 2010)

\section{Fact Sheet \#71: Internship Programs Under The Fair Labor Standards Act}

This fact sheet provides general information to help determine whether interns must be paid the minimum wage and overtime under the Fair Labor Standards Act for the services that they provide to "for-profit" private sector employers.

\section{Background}

The Fair Labor Standards Act (FLSA) defines the term "employ" very broadly as including to "suffer or permit to work." Covered and non-exempt individuals who are "suffered or permitted" to work must be compensated under the law for the services they perform for an employer. Internships in the "for-profit" private sector will most often be viewed as employment, unless the test described below relating to trainees is met. Interns in the "for-profit" private sector who qualify as employees rather than trainees typically must be paid at least the minimum wage and overtime compensation for hours worked over forty in a workweek."

\section{The Test For Unpaid Interns}

There are some circumstances under which individuals who participate in "for-profit" private sector internships or training programs may do so without compensation. The Supreme Court has held that the term "suffer or permit to work" cannot be interpreted so as to make a person whose work serves only his or her own interest an employee of another who provides aid or instruction. This may apply to interns who receive training for their own educational benefit if the training meets certain criteria. The determination of whether an internship or training program meets this exclusion depends upon all of the facts and circumstances of each such program.

The following six criteria must be applied when making this determination:

1. The internship, even though it includes actual operation of the facilities of the employer, is similar to training which would be given in an educational environment;

2. The internship experience is for the benefit of the intern;

3. The intern does not displace regular employees, but works under close supervision of existing staff;

4. The employer that provides the training derives no immediate advantage from the activities of the intern; and on occasion its operations may actually be impeded;

5. The intern is not necessarily entitled to a job at the conclusion of the internship; and

6. The employer and the intern understand that the intern is not entitled to wages for the time spent in the internship.

If all of the factors listed above are met, an employment relationship does not exist under the FLSA, and the Act's minimum wage and overtime provisions do not apply to the intern. This exclusion from the definition of employment is necessarily quite narrow because the FLSA's definition of "employ" is very broad. Some of the most commonly discussed factors for "for-profit" private sector internship programs are considered below. 
Similar To An Education Environment And The Primary Beneficiary Of The Activity

In general, the more an internship program is structured around a classroom or academic experience as opposed to the employer's actual operations, the more likely the internship will be viewed as an extension of the individual's educational experience (this often occurs where a college or university exercises oversight over the internship program and provides educational credit). The more the internship provides the individual with skills that can be used in multiple employment settings, as opposed to skills particular to one employer's operation, the more likely the intern would be viewed as receiving training. Under these circumstances the intern does not perform the routine work of the business on a regular and recurring basis, and the business is not dependent upon the work of the intern. On the other hand, if the interns are engaged in the operations of the employer or are performing productive work (for example, filing, performing other clerical work, or assisting customers), then the fact that they may be receiving some benefits in the form of a new skill or improved work habits will not exclude them from the FLSA's minimum wage and overtime requirements because the employer benefits from the interns' work.

\section{Displacement And Supervision Issues}

If an employer uses interns as substitutes for regular workers or to augment its existing workforce during specific time periods, these interns should be paid at least the minimum wage and overtime compensation for hours worked over forty in a workweek. If the employer would have hired additional employees or required existing staff to work additional hours had the interns not performed the work, then the interns will be viewed as employees and entitled compensation under the FLSA. Conversely, if the employer is providing job shadowing opportunities that allow an intern to learn certain functions under the close and constant supervision of regular employees, but the intern performs no or minimal work, the activity is more likely to be viewed as a bona fide education experience. On the other hand, if the intern receives the same level of supervision as the employer's regular workforce, this would suggest an employment relationship, rather than training.

\section{Job Entitlement}

The internship should be of a fixed duration, established prior to the outset of the internship. Further, unpaid internships generally should not be used by the employer as a trial period for individuals seeking employment at the conclusion of the internship period. If an intern is placed with the employer for a trial period with the expectation that he or she will then be hired on a permanent basis, that individual generally would be considered an employee under the FLSA.

\section{Where to Obtain Additional Information}

This publication is for general information and is not to be considered in the same light as official statements of position contained in the regulations.

For additional information, visit our Wage and Hour Division Website: $\underline{h t t p: / / w w w . w a g e h o u r . d o l . g o v ~}$ and/or call our toll-free information and helpline, available 8 a.m. to 5 p.m. in your time zone, 1-8664USWAGE (1-866-487-9243).

\section{U.S. Department of Labor}

1-866-4-USWAGE

Frances Perkins Building

Washington, DC 20210

" The FLSA makes a special exception under certain circumstances for individuals who volunteer to perform services for a state or local government agency and for individuals who volunteer for humanitarian purposes for private non-profit food banks. WHD also recognizes an exception for individuals who volunteer their time, freely and without anticipation of compensation for religious, charitable, civic, or humanitarian purposes to non-profit organizations. Unpaid internships in the public sector and for non-profit charitable organizations, where the intern volunteers without expectation of compensation, are generally permissible. WHD is reviewing the need for additional guidance on internships in the public and non-profit sectors. 


\section{Appendix B}

Fact Sheet \#71: Internship Programs Under The Fair Labor Standards Act (Updated Jan. 2018)

\section{Wage and Hour Division (WHD)}

(Updated January 2018) (PDF)

\section{Fact Sheet \#71: Internship Programs Under The Fair Labor Standards Act}

This fact sheet provides general information to help determine whether interns and students working for "for-profit" employers are entitled to minimum wages and overtime pay under the Fair Labor Standards Act (FLSA). $\underline{1}$

\section{Background}

The FLSA requires "for-profit" employers to pay employees for their work. Interns and students, however, may not be "employees" under the FLSA-in which case the FLSA does not require compensation for their work.

\section{The Test for Unpaid Interns and Students}

Courts have used the "primary beneficiary test" to determine whether an intern or student is, in fact, an employee under the FLSA. In short, this test allows courts to examine the "economic reality" of the intern-employer relationship to determine which party is the "primary beneficiary" of the relationship. Courts have identified the following seven factors as part of the test:

1. The extent to which the intern and the employer clearly understand that there is no expectation of compensation. Any promise of compensation, express or implied, suggests that the intern is an employee-and vice versa.

2. The extent to which the internship provides training that would be similar to that which would be given in an educational environment, including the clinical and other hands-on training provided by educational institutions.

3. The extent to which the internship is tied to the intern's formal education program by integrated coursework or the receipt of academic credit.

4. The extent to which the internship accommodates the intern's academic commitments by corresponding to the academic calendar.

5. The extent to which the internship's duration is limited to the period in which the internship provides the intern with beneficial learning.

6. The extent to which the intern's work complements, rather than displaces, the work of paid employees while providing significant educational benefits to the intern.

7. The extent to which the intern and the employer understand that the internship is conducted without entitlement to a paid job at the conclusion of the internship.

Courts have described the "primary beneficiary test" as a flexible test, and no single factor is determinative. Accordingly, whether an intern or student is an employee under the FLSA necessarily depends on the unique circumstances of each case.

If analysis of these circumstances reveals that an intern or student is actually an employee, then he or she is entitled to both minimum wage and overtime pay under the FLSA. On the other hand, if the analysis confirms that the intern or student is not an employee, then he or she is not entitled to either minimum wage or overtime pay under the FLSA.

Where to Obtain Additional Information

This publication is for general information and is not a regulation. For additional information, visit our Wage and Hour Division Website: http://www.wagehour.dol.gov and/or call our toll-free information and helpline, available $8 \mathrm{a.m}$. to 5 p.m. in your time zone, 1-866-4USWAGE (1-866-487-9243).

\section{Footnotes}

1 - The FLSA exempts certain people who volunteer to perform services for a state or local government agency or who volunteer for humanitarian purposes for non-profit food banks. WHD also recognizes an exception for individuals who volunteer their time, freely and without anticipation of compensation, for religious, charitable, civic, or humanitarian purposes to non-profit organizations. Unpaid internships for public sector and non-profit charitable organizations, where the intern volunteers without expectation of compensation, are generally permissible.

2 - E.g., Benjamin v. B \& H Educ., Inc., --- F.3d ---, 2017 WL 6460087, at *4-5 (9th Cir. Dec. 19, 2017); Glatt v. Fox Searchlight Pictures, Inc., 811 F.3d 528, 536-37 (2d Cir. 2016); Schumann v. Collier Anesthesia, P.A., 803 F.3d 1199, 1211-12 (11th Cir. 2015); see also Walling v. Portland Terminal Co., 330 U.S. 148, 152-53 (1947); Solis v. Laurelbrook Sanitarium \& Sch., Inc., 642 F.3d 518, 529 (6th Cir. 2011). 
Appendix C

Summary of Benefits, Drawbacks and Legal Issues of Internships

\begin{tabular}{|c|c|c|c|c|}
\hline \multicolumn{5}{|c|}{ Benefits } \\
\hline All Internships & $\begin{array}{l}\text { Many provide opportunity for } \\
\text { experiential learning and thus } \\
\text { higher levels of cultural } \\
\text { competency, understanding of } \\
\text { field, and career preparation } \\
\text { (Simons et al., 2012) }\end{array}$ & $\begin{array}{l}\text { Boost career outcomes (Guarise \& } \\
\text { Kostenblatt, 2018) }\end{array}$ & $\begin{array}{l}\text { Boost soft skill development } \\
\text { (Stack \& Fede, 2017) }\end{array}$ & $\begin{array}{l}\text { Internships are "the single most } \\
\text { important credential for recent } \\
\text { college graduates to have on their } \\
\text { resume in their job search among } \\
\text { all industry segments" ("The role } \\
\text { of higher education," 2012, p. 11) }\end{array}$ \\
\hline Paid Internships & $\begin{array}{l}\text { On top of experiential learning, } \\
\text { provides financial compensation } \\
\text { for work (Gardner, 2010) }\end{array}$ & $\begin{array}{l}\text { Provide better short-term career } \\
\text { outcomes (Crain, 2016) }\end{array}$ & $\begin{array}{l}\text { Interns spend more time engaging } \\
\text { in professional activities } \\
\text { (Farthing-Nichol, 2014) }\end{array}$ & $\begin{array}{l}\text { Recieve on average, } \$ 13,000 \\
\text { more than their unpaid } \\
\text { counterparts in their first year } \\
\text { working (Pisko, 2015) }\end{array}$ \\
\hline Unpaid Internships & & $\begin{array}{l}\text { Employers may view an unpaid } \\
\text { intern as more passionate and } \\
\text { willing to volunteer, boosting the } \\
\text { interns status in a potential } \\
\text { employer's mind (Saltikoff et al., } \\
\text { 2018) }\end{array}$ & $\begin{array}{l}\text { Employers say there is no } \\
\text { discernible difference in the work } \\
\text { ethic of paid and unpaid interns } \\
\text { ("The role of higher education," } \\
\text { 2012, p. 84) }\end{array}$ & $\begin{array}{l}\text { In hiring decisions, ranked by } \\
\text { employers as better than volunteer } \\
\text { work and enrollment in a } \\
\text { graduate/certification program } \\
\text { ("The role of higher education," } \\
\text { 2012, p. 84) }\end{array}$ \\
\hline \multicolumn{5}{|c|}{ Drawbacks } \\
\hline All Internships & $\begin{array}{l}\text { Risk of menial work (Farthing- } \\
\text { Nichol, 2014) }\end{array}$ & & & \\
\hline Paid Internships & $\begin{array}{l}\text { Risk of using compensation as an } \\
\text { excuse to treat as workers, not } \\
\text { "primary beneficiaries" of } \\
\text { education (Fact Sheet } \# 71,2018 \text { ) }\end{array}$ & & & \\
\hline Unpaid Internships & $\begin{array}{l}\text { Lower levels of satisfaction than } \\
\text { paid interns (Crain, 2016) }\end{array}$ & $\begin{array}{l}\text { No financial compensation for } \\
\text { work, which risks barring low- } \\
\text { income individuals from engaging } \\
\text { in unpaid internships (Fink, 2013) }\end{array}$ & $\begin{array}{l}\text { Higher risk of menial, clerical } \\
\text { work and may lag bchind in } \\
\text { professional, skill-building } \\
\text { activities (Farthing-Nichol, 2014) }\end{array}$ & $\begin{array}{l}\text { Compared to paid internships, } \\
\text { worse career outcomes in the } \\
\text { short term (Crain, 2016) }\end{array}$ \\
\hline \multicolumn{5}{|c|}{ Legal Issues } \\
\hline All Internships & $\begin{array}{l}\text { Universities/program } \\
\text { administrators may be held liable } \\
\text { for harms inflicted upon a student } \\
\text { while at their internship (Gross v } \\
\text { Family Services Agency and Nova } \\
\text { Southeastern University, 1998) }\end{array}$ & & & \\
\hline Paid Internships & $\begin{array}{l}\text { Interns are considered employees } \\
\text { and thus are protected by federal } \\
\text { employment law (Yamada, 2016) }\end{array}$ & & & \\
\hline Unpaid Internships & $\begin{array}{l}\text { Under the revised } 2018 \text { Fact Sheet } \\
\text { \#71 it has become easier for for- } \\
\text { profit companies to offer unpaid } \\
\text { internships (Greenfield, 2018) }\end{array}$ & $\begin{array}{l}\text { Interns may not be afforded the } \\
\text { same federal legal protections as } \\
\text { employees (Svacina, 2012) }\end{array}$ & & \\
\hline
\end{tabular}


References

Andrews, J., \& Higson, H. (2008). Graduate Employability, 'Soft Skills' Versus 'Hard' Business Knowledge: A European Study. Higher Education in Europe, 33(4), 411-422. https://doi.org/10.1080/03797720802522627

Bacon, N. (2011). Unpaid Internships: The History, Policy, and Future Implications of Fact Sheet \#71, 6, 67-96. Retrieved from heinonline.org

Brooks, J. E., \& Greene, J. C. (1998). Benchmarking Internship Practices: Employers Report on Objectives and Outcomes of Experiential Programs. Journal of Career Planning \& Employment, 59(1), 37-39, 57-60.

Budd, P. (2015). All Work and No Pay: Establishing the Standard for When Legal, Unpaid Internships Become Illegal, Unpaid Labor. Kansas Law Review, 63(2), 451-495.

Burke, D. D., \& Carton, R. (2013). The Pedagogical, Legal, and Ethical Implications of Unpaid Internships. Journal of Legal Studies Education, 30(1), 99-130.

Cantor, J. A. (1997). Experiential learning in higher education: linking classroom and community. Washington, DC: Graduate School of Education and Human Development, The George Washington University.

The role of higher education in career development: employer perceptions [PowerPoint Slides]. (2012). Washington: Chronicle of Higher Education. Retrieved from http://chronicle.com/items/biz/pdf/Employers\%20Survey.pdf

Crain, A. (2016). Understanding the Impact of Unpaid Internships on College Student Career Development and Employment Outcomes. NACE Journal https://www.naceweb.org/uploadedfiles/files/2016/guide/the-impact-of-unpaid-internshipson-career-development.pdf

Curiale, J. (2010). America's New Glass Ceiling: Unpaid Internships, the Fair Labor Standards Act, and the Urgent Need for Change. Hastings Law Journal, 61, 101-128.

Daniel, R., \& Daniel, L. (2013). Enhancing the transition from study to work: Reflections on the value and impact of internships in the creative and performing arts. Arts and Humanities in Higher Education, 12(2-3), 138-153.

DiRienzo, D.F. (2016). Student Perceptions of Unpaid Internships in the Arts, Entertainment, and Media Industry: A Survey of Lower Income Students' Ability to Participate in Internships (Doctoral dissertation). Retrieved https://fisherpub.sjfc.edu/education_etd

Durrant, C. (2013). To Benefit or Not to Benefit: Mutually Induced Consideration As a Test for the Legality of Unpaid Internships. Univ. of Pennsy/vania Law Review, 162, 169-202.

Easterly, E. J. (2018, January 23). New Guidelines for Internships: The New Unpaid Intern Test. Retrieved from https://www.naceweb.org/public-policy-and-legal

Eisenbrey, R. (2012, January 5). Unpaid internships hurt mobility. Retrieved June 23, 2018, from https://www.epi.org/blog/unpaid-internships-economic-mobility/

Fair Labor Standards Act of 1938, 29 U.S.C. § 203.

Farthing-Nichol, D. (2014). Social Mobility in the New Economy: Transforming Unpaid Internships through an Educational Inquiry Test, 23.

Federal Intern Protection Act of 2017, H.R. 653, 115th Cong. (2017).

Fewer unpaid internships to be offered, report says. (2015, November 2). Retrieved June 23, 2018, from https://www.nbcnews.com/business/business-news

Finch, D. J., Hamilton, L. K., Baldwin, R., \& Zehner, M. (2013). An exploratory study of factors affecting undergraduate employability. Education + Training, 55(7), 681-704. 
Fink, E. M. (2013). No Money, Mo' Problems: Why Unpaid Law Firm Internships are Illegal \& Unethical. University of San Francisco Law Review, 47, 1-25.

Gardner, P. (2010). The Debate Over Unpaid College Internships. Intern Bridge. Retrieved from http://www.ceri.msu.edu/wp-content/uploads/2010/01/Intern-Bridge-Unpaid-CollegeInternship-Report-FINAL.pdf

Greenfield, R. (2018, January 10). Unpaid Internships Are Back with the Labor Department's Blessing. Bloomberg.

Greenhouse, S. (2010, April 2). The Unpaid Intern, Legal or Not. The New York Times.

Greenhouse, S. (2012, May 2). Jobs Few, College Graduates Flock to Unpaid Internships. The New York Times.

Greenhouse, S. (2013, June 11). Judge Rules for Interns Who Sued Fox Searchlight. The New York Times.

Gross v. Family Services Agency and Nova Southeastern University, 716 So.2d 337 (1998). Guarise, D., \& Kostenblatt, J. (2018, February 1). Unpaid Internships and the Career Success of Liberal Arts Graduates. Retrieved from https://www.naceweb.org/jobmarket/internships/unpaid-internships-and-the-career-success-of-liberal-arts-graduates/

Haque, W. (2017). Experiential Learning: Beyond the Classroom and Connecting with the Industry. In A. Tatnall \& M. Webb (Eds.), Tomorrow's Learning: Involving Everyone. Learning with and about Technologies and Computing (Vol. 515, pp. 443-452). Cham: Springer International Publishing.

Hickman, B. \& Thompson, C. (2013, August 9). How Unpaid Interns Aren't Protected Against Sexual Harassment [text/html]. Retrieved June 23, 2018, from https://www.propublica.org/article/how-unpaid-interns-arent-protected-against-sexual

Johnson, T. (2016). The Fox Searchlight Signal: Why Fox Searchlight Marks the Beginning of the End for Preferential Treatment of Unpaid Internships at Nonprofits. Virginia Law Review, 102(4), 11281162.

Kolb, D. A. (1984). Experiential learning: experience as the source of learning and development. Englewood Cliffs, N.J: Prentice-Hall.

Lachman, S. (2015, May 27). A Shocking Number of States Don't Protect Unpaid Interns From Discrimination And Sexual Harassment. Huffington Post.

Mihelich, M. (2013, June 14). Federal Court Says "Black Swan" Interns Should Have Been Paid. Workforce Magazine.

Miller, D. (2016, July 12). Fox unpaid intern case is drawing to a close with proposed settlement. LA Times.

Moran, T.J. (2013). Study of interns' perception of and satisfaction with experiential learning (Doctoral dissertation). Retrieved from ProQuest Dissertations and Theses database.

New DOL rule loosens restrictions on unpaid internships. (2018). HR Specialist: Minnesota Employment Law, 11(3), 7.

Pasternack, C. A. (2015). No Pay, No Gain? The Plus Side of Unpaid Internships. The Journal of Business, Entrepreneurship \& the Law, 8(1), 193-218.

Pellegrino, J. W., \& Hilton, M. L. (2012). Education for Life and Work: Developing Transferable Knowledge and Skills in the 21st Century. Washington, D.C.: National Academies Press.

Pisko, S. A. (2015). Great Expectations, Grim Reality: Unpaid Interns and the Dubious Benefits of the Dol Pro Bono Exception. Seton Hall Law Review, 45(2), 613-645.

Recent US Labor Market Data (ILO-USA). (2013, June). Retrieved June 23, 2018, from http://www.ilo.org/washington/ilo-and-the-united-states/spot-light-on-the-us-labormarket/recent-us-labor-market-data/lang--en/index.htm 
Reid, P. L. (2015). Fact Sheet \#71: Shortchanging the Unpaid Academic Intern. Florida Law Review, 66, 1375-1402. Retrieved from https://scholarship.law.ufl.edu/flr/vol66/iss3/9/.

Saltikoff, N., Albers, A., Rossi-Le, L., \& Hall, E. (2018). Unpaid Internships and Early Career Outcomes. NACE Journal.

Sanahuja Vélez, G., \& Ribes Giner, G. (2015). Effects of Business Internships on Students, Employers, and Higher Education Institutions: A Systematic Review. Journal of Employment Counseling, 52(3), 121-130. https://doi.org/10.1002/joec.12010

Schoepfer, K. L., \& Dodds, M. (2010). Internships in Sports Management Curriculum: Should Legal Implications of Experiential Learning Result in the Elimination of the Sport Management Internship? Marquette Sports Law Review, 21(1), 183-201.

Simons, L., Fehr, L., Blank, N., Connell, H., Georganas, D., Fernandez, D., \& Peterson, V. (2012). Lessons Learned from Experiential Learning: What Do Students Learn from a Practicum/Internship? International Journal of Teaching and Learning in Higher Education, 24(3), 325-334. Retrieved from https://eric.ed.gov/?id=EJ1000685.

Stack, K., \& Fede, J. (2017, August 1). Internships as a Pedagogical Approach to Soft-Skill Development. Retrieved June 23, 2018, from http://www.naceweb.org/career-readiness /internships/internships-as-a-pedagogical-approach-to-soft-skill-development/

Sterbenz, C. (2013, June 12). Victory for Interns - Business Insider. Retrieved June 23, 2018, from http://www.businessinsider.com/victory-for-interns-2013-6

Svacina, L. S. (2012). A review of research on unpaid internship legal issues: implications for career services professionals. Cooperative Education \& Internship Assoc., 46, 77-87.

The Age Discrimination in Employment Act, 29 U.S.C. §§ 621-634.

The Americans with Disabilities Act, 42 U.S.C. §§ 12101-12214.

Title VII of the Civil Rights Act of 1964, 42 U.S.C. § 2000e-2.

Townsley, E., Lierman, L., Watermill, J., \& Rousseau, D. (2017). The Impact of Undergraduate Internships on Post-Graduate Outcomes for the Liberal Arts. Retrieved from http://www.naceweb.org/uploadedfiles/files/2017/publication/report/2017-nace-impact-ofinternships-on-liberal-arts-report.pdf

U.S. Department of Labor Wage and Hour Division. (2010). Fact Sheet \#71: Internship Programs Under The Fair Labor Standards Act [Fact sheet]. Retrieved from https://dornsife.usc.edu/assets/sites/1078/docs/internship_fed_doc.pdf

U.S. Department of Labor Wage and Hour Division. (2018). Fact Sheet \#71: Internship Programs Under The Fair Labor Standards Act [Fact sheet].

Walling v. Portland Terminal Co., 330 U.S. 148 (1947).

Wang v. Phoenix Satellite Television US, Inc., 976 F.Supp.2d 527 (2013).

Weissmann, J. (2013, June 12). The Court Ruling That Could End Unpaid Internships for Good. The Atlantic.

Yamada, D. C. (2016). The Legal and Social Movement Against Unpaid Internships. Northeastern University Law Journal, 8(2), 357-396. 


\section{About the Author}

Philip C. Rothschild, Ph.D. (philrothschild@missouristate.edu) is Associate Professor of Entertainment Management at Missouri State University in Springfield, Missouri. His research interests are in the areas of leadership, social media use, and stakeholder management. He has experience as a personal manager in the publishing industry, and provides advice to non-profit theatres, event management companies, and authors.

Connor L. Rothschild (connorrothschild@gmail.com) is a senior at Rice University studying Social Policy Analysis and Political Science. His research interests lie in criminal justice policy, disaster resilience, and economic policy. Prior to joining the Texas Policy Lab, Connor held research positions in the Baker Institute's McNair Center for Entrepreneurship and Innovation and in the Political Science department at Rice University. 